\title{
The Re-Evaluation of Existing School Buildings in Turkey within the Context of 'Green School'
}

\author{
Sağra Çakır ${ }^{\oplus}$, Gökçe Tuna Taygun 2 ๑
}

\begin{abstract}
1 Master Architect, Republic of Turkey Ministry of Culture and Tourism, 06250 Ankara, Turkey (Corresponding Author). Email: sagra.cakir@gmail.com

${ }^{2}$ Assoc. Prof. Dr., Yıldız Technical University, Faculty of Architecture Department of Architecture, 34349 Istanbul, Turkey, Email: tuna@yildiz.edu.tr
\end{abstract}

\begin{abstract}
Purpose

It is seen that major repairs and refurbishments in existing school buildings in Turkey are mostly intended for structural reinforcement and physical facilities, and the Green School design principles are not considered in the process of the new school designs and refurbishment applications in existing schools. Moreover, the participation of students, teachers and parents in "environmental decisions" in design process regarding school building and its environment is not ensured sufficiently. The purpose of the research is to determine of the knowledge, views, wishes and tendencies of the students, teachers and parents which are the three main components of the school community related to the general characteristics of the school building and its contribution to environmental education.
\end{abstract}

Design/Methodology/Approach

A questionnaire form was used as a tool. The survey was conducted in two secondary schools in Ankara in 2017-2018 academic year. Data were analyzed with SPSS 24.0 with the help of experts.

\section{Findings}

The majority of the participants believe that the open spaces in the schools do not provide enough opportunities for interaction with the natural environment, the green spaces in the schools are not sufficient in terms of quality and quantity, the noise in the classrooms is clearly disturbing, but the artificial lighting, temperature and ventilation were found to be relatively adequate.

\section{Research Limitations/Implications}

When selecting the schools, it was among the schools that are planned to be maintained and repaired in the 2018-2019 academic year by the Ministry of National Education and the schools built after 1990 taking into consideration compliance with today's conditions and the adaptability of technological systems.

Originality/Value

This research stimulates readers and stakeholders to discuss the environmental education provided to the future decision makers (children) through the school buildings.

Keywords: Environment, environmental education, green schools, green school design criteria, school buildings 


\section{INTRODUCTION AND LITERATURE REVIEW}

Research on green buildings shows that school buildings constitute the fastest growing sector in the green building industry. A large extent of green building design principles are adopted in the construction and renovation of school buildings, and the importance given to these principles is growing around the world (Yudelson, 2008: 1-5, Kats, 2006: 2-7). The concept of 'green schools' was first introduced by the United States Green Building Council (USGBC). The Council launched the national green schools campaign in 2007, and in addition to the LEED certification system established by the Council, the LEED Schools (LEED$\mathrm{SCH}$ ) organization was created to measure and evaluate the environmental performance of school buildings (USGBC, 2009: 10). In 2010, the Center for Green Schools was established within the USGBC. The objective of the Center for Green Schools is to direct the transformation of all schools into sustainable and healthy places for living, learning, working and playing. In 2013, the Green Schools Project was initiated with the cooperation of the World Green Building Council (WGBC), the Center for Green Schools, and the National Green Building Councils. The Green Schools Project is defined as "an international and multi-stakeholder project to provide students with the opportunity to be educated in healthier, safer and more efficient buildings", with the aim of "educating new generations in healthier buildings to contribute to the raising of an academically more successful generation" (Green Buildings Reference Guide, 2014: 4). Within the scope of the project, the Global Coalition For Green Schools was established. In 2013, Turkey signed the green schools agreement at the World Green Buildings Council in Cape Town as a founding member along with 29 other countries.

According to Ministry of Education statistics, in 2017-2018, there were about 98 thousand school buildings in Turkey, 24 million students, and 1 million 300 thousand teachers (MEB, 2018: 18-21). In addition, statistics indicate that almost one third of the Turkish population spends a good part of their day in school buildings. Therefore, the current conditions of school buildings are important in every aspect. In Turkey, the 'Minimum Design Standards Guide for School Buildings' was published by the Ministry of National Education in 2013 with regard to constructing new school buildings and renovating existing ones. Renewed in 2015, this guide stated that approximately 50\% of school buildings in Turkey are over 25-years old, and that there is a need to refurbish these buildings so that they comply with the principles of providing educational services and respond to new requirements in education and training (Avcl, 2013: VIII). Furthermore, according to 2017 Ministry of National Education statistics, the largest part of the budget is reserved for major repairs and facilities (MEB, 2017: 239247). However, it has been observed that major repairs and renovations to existing school buildings are mostly aimed at structural strengthening and the improvement of physical facilities. Green building design 
The Re-Evaluation of Existing School Buildings in Turkey within the Context of 'Green School'

principles and certification systems are not considered important input in new school designs and when existing schools are renewed, there is no obligation to comply with these principles. In addition, it is observed that the participation of students, teachers and parents in "environmental decisions" regarding the design processes of school buildings and their surroundings.

In this context, participation is the process of communication between the population living in an area being planned and the experts doing the planning, where the target groups use the current situation to help guide and determine the factors for the analysis, planning, evaluation, and implementation necessary to solve the existing problems in that area (Saltık, 1997: 27-33). Thuswise, participation techniques are used to create successful physical environments and the data obtained is used in school designs. Accordingly, every building is constructed in a way that will address its region and residents. Thus, schools can be designed as community centers that will satisfy students, parents, managers and teachers (Özbayraktar, 2005: 101-108).

Economic insufficiencies lead to the development and implementation of typical projects pertaining to school buildings and these practices cause various physical and socio-cultural problems at both the individual and social aspects. It is well understood that investments made into school buildings that reflect changing educational programs and developing technology contribute to society in a versatile way and with long-term gain. In this context, there are many studies in the literature analyzing the effects of green schools on the environment, on the health and education of students, as well as the fact that green schools can be used as an effective tool in environmental education (Taylor, 2013: 3; Gelfand and Freed, 2010: 13).

For example; Cole (2013), in his study titled "The Green Building as a Medium for Environmental Education", which is among the disciplines of architecture and environmental education, focused on the contribution of the physical environment to environmental education. It emphasized that school buildings can be used as an important tool to increase environmental literacy. According to Bradley (1996) who studies the effect of architecture on education; declares as a tool that supports the curriculum and makes the teaching experience more meaningful, architectural design should serve as a textbook for students. Taylor (2013) states that investing in school buildings are a "triple win" for communities (Figure 1). 


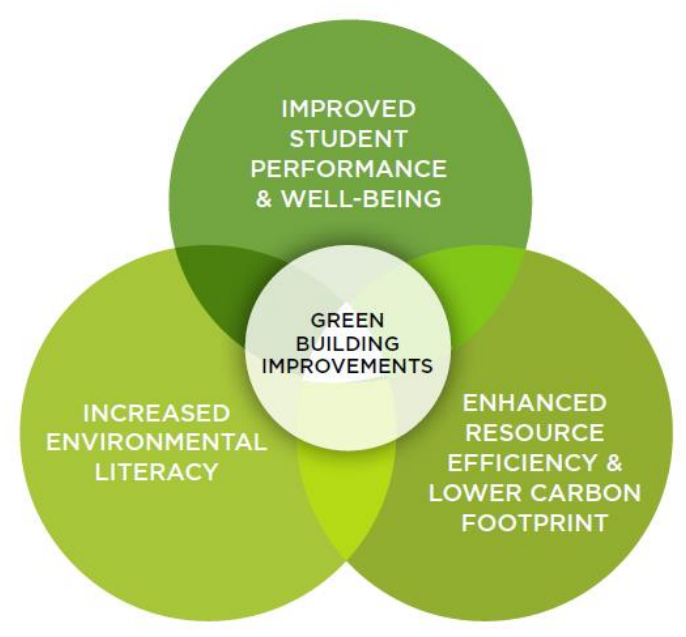

In his study, Hines (1996) observed the connection between the situation of school facilities, student achievement and student behavior. The results of this study show that student achievement scores were higher in schools with better building situations, and student discipline incidents were higher in schools with better building situation. Science achievement results were better in buildings with better science laboratory conditions. In conclusion, changing climate control, locker and grafitti conditions were causes which positively associated with student achievement scale scores.

Oetinger (2010), in his study titled "Green schools: Constructing and renovating school facilities with the concept of sustainability", examined the effects of green schools on the environment, students' health and education and stated that green schools have a positive effect on learning, reduce the financial costs of the school, and reduce absenteeism.

According to the study conducted by Barrett and Zhang (2013) to investigate whether school building design has any demonstrable effect on the learning speed of students in primary schools in England, school layout affects a child's development at the level of $25 \%$, either positively or negatively. The study showed that six classroom design factors (color, preference, connectivity, complexity, flexibility, and light) were clearly correlated with grade scores.

In the studies on the benefits of implementing sustainable design features in newly constructed and renewed school facilities, the following points are underlined. Constructing and renovating school buildings based on the concepts of sustainability will:

-minimize waste and the consumption of resources and thus will reduce the overall impact on the environment,

- be effective in reducing operation and maintenance costs,

-help decrease student and staff absenteeism, increasing motivation and academic success,

-protect users' health, provide an efficient (productive) learning environment, connect students to the natural world, and increase daily
Figure 1. "Triple win" for communities (Taylor, 2013). 
The Re-Evaluation of Existing School Buildings in Turkey within the Context of 'Green School'

average participation (Berry, 2002: 19; Ford, 2007: 4; Edwards, 2006: 14-29).

Many studies are conducted to examine the physical conditions of schools that are often related to the field of educational science exist in Turkey on environmental education and on the impact of student achievement regardless of green school design criteria.

In the study by Gök and Gürol (2002), in which the use of primary schools in terms of time and ergonomics, a questionnaire was applied to 110 administrators of primary schools in Elazig in the 1998-1999 academic year, and it was found that the physical units in the school were used above their capacities. It is concluded that it is used very little other segments of the society and ergonomic use of school buildings and units is not given importance. In the study, it was emphasized that the schools were inadequate in terms of ergonomics, and the most inadequate in terms of ergonomics in all units was the acoustic layout, color harmony and ventilation, and the opinion of various experts (architect, educator, child development specialist, doctor, behavioral scientist) should be taken when constructing new school buildings.

In the study of Özdemir and Çorakçı (2011), it was aimed to develop environmental awareness in children as well as to examine the effects of school gardens on child development and healthy life, and by conducting surveys with 1729 students in 5 schools in Ankara, teachers' opinions were taken and school gardens were redesigned accordingly. As a result of the research, it was found that children who were active during the break were healthier, some students spent their recess time in the school due to the short break time and the lack of gardens for activities, most of the students liked schools with large gardens and were not satisfied with school gardens with low landscape values. The results of this study show that greener and well-maintained school gardens will support physical activity by changing students' view of the environment and playing habits, and that sustainable school environments can be created with the participation of students.

In the study conducted by Seven and Engin (2008) to determine the factors affecting learning, it was observed that, according to the results of the questionnaire they applied to students, the most important negative factors affecting learning were external factors, and these factors were the physical condition of the school and the students' inability to receive as much support from their families economically. Some of the students participating in the questionnaire stated that the primary education institutions they study at are not getting heated enough, their schools are located in a very noisy place due to their location, and they cannot benefit from places such as workshops or laboratories as much as they need. Atasoy and Ertürk (2008), in their study to determine the environmental attitudes and knowledge of primary school 6th, 7th and 8th grade students, showed that primary school students were not at a sufficient level in terms of both environmental knowledge and 
environmental attitude, the quality, scope and depth of environmental education provided in primary education. They stated that the reasons such as negative and insufficient content of the curriculum, the inadequacy of the textbooks for education for the environment, the education environment, the quality of the teachers, the less environmentalization of the lessons are the main reasons for the low environmental knowledge.

In the study conducted by Karatekin and Çetinkaya (2013) in order to evaluate the primary school gardens in the city center of Manisa in terms of environmental education, an evaluation form measuring the adequacy of school gardens were developed by the researchers. As a result of the evaluation, the usage areas of the primary school gardens in the city center of Manisa are far below the standards in developed countries and the area of the school gardens included in the study is covered with concrete or asphalt, so the amount of green space per student is very low. It was stated that there were no bushy areas with few trees and flowering areas in the area, there were either no or insufficient equipment in a school yard for environmental education, and 32 primary schools included in the study were insufficient in terms of environmental education.

It is clear that many existing school buildings in Turkey are not consistent with the concept of green schools and that society is not sufficiently aware of the individual, social, and economic contributions of green schools. Additionally, although the number of school buildings with green building certificates has been increasing, it is seen that certified school buildings are mostly higher education buildings and/or private education institutions within universities. Considering the fact that children are easily affected by their environment in terms of health as well as the importance of environmental education at an early age, green building design benchmarks should be developed, implemented, and made obligatory not only for private educational institutions but also for pre-school, primary and secondary school buildings. To create successful physical environments, it is also important to consult users, as their opinions will be guiding and determining factors.

\section{METHODOLOGY}

In the research, a comprehensive "survey" was conducted to re-evaluate school buildings and the concept of "green schools" was assessed based on the selected schools. Firstly, the current status and general characteristics of the selected schools were examined, and their negative/positive aspects were determined. Data was collected through a survey prepared according to a review of the literature on the concept of "green schools". The questionnaire consisted of seven sections:

- The first section included questions about general and demographic characteristics,

- The second section was about the relationship between the school and the environment, and also about environmental education, 
The Re-Evaluation of Existing School Buildings in Turkey within the Context of 'Green School'

- The third section had questions about the general characteristics of the school building and its contribution to environmental education,

- The fourth section focused on general opinions about classrooms,

- The fifth, sixth and seventh sections had open-ended questions aimed at identifying wishes and tendencies regarding the positive/negative characteristics of environmental education in and around the school building.

The data was analyzed using the SPSS 24.0 program and the results were evaluated at 95\% confidence level. Construct validity and reliability analyses were performed in order to determine the factor structure and reliability level of the scales. The construct validity of the scale was determined according to Exploratory Factor Analysis (EFA), and Cronbach's alpha reliability coefficients were calculated to determine its reliability. The scale scores in the study were calculated based on the following metric:

- I have no idea/I do not know: 0

- I strongly disagree: 1

- I do not agree: 2

- I am undecided: 3

- I agree: 4

- I strongly agree: 5

Accordingly, the lowest score that can be obtained from the scale is 0 , and the highest score is 5 . Using this scale, the difference between the scores of the students, teachers and parents were analyzed using the ANOVA test. Since classrooms are the places where education, training, and learning activities are carried out, and thus most of the time is spent in classrooms, the questionnaire included general opinions about classrooms as well. In this regard, this study is a statistical evaluation. In line with the data analysis in the questionnaire, tables were prepared to indicate the distribution of answers regarding the positive and negative opinions of the students, teachers, and parents about certain features of the building as well as the distribution of answers given to questions regarding the comfort conditions of the classrooms.

In the 2017-2018 academic year, a total of 143 students, 7 teachers and 117 parents from two secondary schools (The article will be referred to as X Secondary School and Y Secondary School) in Yenimahalle District of Ankara Province were surveyed and the general characteristics and current situations of the schools were examined. According to the findings of international studies on environmental education, the education level at which individuals can receive environmental education in the most efficient way is secondary education (Ünal and Dımışkı 1999; IEEP, 1994). Considering the awareness level and age of the students, the survey was conducted with 8th grade students in secondary schools. When examining education programs in Turkey; there are units with titles as "Human and Environment", "Creatures and Life", "Energy Conversions and Environmental Science" etc. in the science lessons of primary and secondary school 3,4,5,6,7 and 8th 
grades. Depending on the education program, an awareness and perception of the concept of environment occurs in students. Students constitute the majority of the user group in school buildings. For this reason, it was not necessary to explain the questions as they were expected to respond to the questions in the questionnaire with the students' perception of the school building and its surroundings and their perspective. In the process of selecting the schools; first of all, by contacting the Provincial Directorate of National Education Construction Real Estate Branch, information was obtained about the secondary schools that are planned to be maintained and repaired in the 20182019 academic year. Secondly, among these secondary schools those with wide / developable land conditions and those constructed after the year of 1990 were determined, considering the adaptation to today's conditions and the adaptability of technological systems. Afterwards, 2 secondary schools that met these conditions were selected. In order to minimize the variables related to physical environmental conditions, the selected schools are in the same neighborhood.

\section{CONSEPT AND DESIGN PRINCIPLES OF GREEN SCHOOLS}

Edwards (2006) states that there are four important characteristics to define a green school:

-Resource efficient,

-Physically and psychologically healthy,

-Comfortable, adaptable/sensitive and flexible,

-Based on ecological principles.

Earthman (2009) defines green schools as mechanisms that are saving energy and water and designed from materials that do not harm the environment. According to Earthman (2009), green schools support their natural environment. Additionally, the outside world is included in building design. When someone walks down the corridors, they'll feel as if nature is responsible for the design. The green school program of the USA, Global Green USA, which works to build and develop healthier and energy efficient school buildings, identifies a green school as a facility that is designed, renovated, operated or reused in an ecological and resource-efficient way.

Center for Green Schools, defines green schools as a school building or facility that creates a healthy environment conducive to learning while saving energy, resources and money. Also, According to WGBC (2013), the quality of the green schools are:

-Less energy consumption during operation with the energy-saving building design,

-High indoor air quality providing improved learning outcomes,

-Removal of toxic materials from learning environments and playgrounds,

-Using daylight strategies,

-Improving classroom acustics,

-Preservation of fresh dirinking water and collecting rainwater, 
The Re-Evaluation of Existing School Buildings in Turkey within the Context of 'Green School'

-Reducing the wastewater management of municipality through water recycling and water efficiency devices and equipment,

-Supporting wastewater management efforts and recycling through decomposition opportunities to reduce the demand for local storage and take advantage of the local community and region.

Green schools are buildings that do not produce waste hazardous to the environment during the processes of design, production, use (operation), reuse, dismantling, demolition and/or destruction. They offer users healthy and comfortable environments, ensuring the efficient use of natural and artificial resources, and contributing to environmental education; thus having a positive effect on the overall quality of education. The difference between green schools and other green buildings is that the field of education emphasizes sustainability and resource conservation and contributes to interactive environmental education. Analyzing studies in the literature (WGBC, 2013: 3-6; Baker and Bernstein, 2012: 1-4; Çakır, 2017: 180-185), it can be observed that the features green schools emphasize the most are the efficient use of resources, protecting the environment, and creating healthy and comfortable environments, as well as seeing the entire school as a learning tool and planning accordingly. In addition, the majority of the user group consists of developmental age children, and it is often underlined that their healthy development is affected by the quality and structural features of their school buildings. Within the scope of green school designing principles, it is also important to create compatible/sensitive and flexible spaces that are adaptable to the quality of education, changes in educational programs, and developing technological innovations.

Scientific studies show that there is a relationship between the physical environment of a school and the performance of students and teachers. According to Baker and Bernstein (2012: 4):

- Studies show that when deprived of natural light, melatonin cycles in children are impaired, which affect levels of attention at school (Figueiro \& Rea, 2010).

- Teachers report that they are more comfortable in classrooms where they have access to temperature controls, be it thermostats or even opening windows (Heschong \& Mahone, 2003; Lackney, 2001).

- Researchers at the Lawrence Berkeley National Laboratories state that when ventilation rates are at or below minimum standards (roughly 15 $\mathrm{cfm}=$ cubic feet per minute per student), a relative reduction of 5 to $10 \%$ occurs in certain aspects of student performance tests.

- Recent studies have shown that when ventilation rates were reduced from $17 \mathrm{cfm}$ to $10 \mathrm{cfm}$ per person, symptom prevalence for Sick Building Syndrome decreased by $15 \%$.

In addition, it is reported that in green schools:

- Daylight and landscaping improve performance,

- High indoor air quality enhances health and concentration,

- Good acoustics increase learning potential, 
- Comfortable indoor temperatures enhance user satisfaction, thus both students and teachers benefit from learning and working in green schools. (WGBC, 2013: 3-6).

With increasing research on green buildings around the world as well as enhanced understanding of their importance, national green building certification systems have been established by green building councils in many countries. In various countries, these green building certification systems also separately specify criteria for schools. Furthermore, some countries have different systems and guidelines regulating criteria that is specific only to schools, in addition to the green building certification systems. Within the scope of green school design principles, Figure 2 shows the respective criteria given in the Turkish guide on school buildings, green school building guides, and green school building certification systems. This classification is an implication made in line with the data obtained from the sources examined and the literature review regarding green school design criteria.

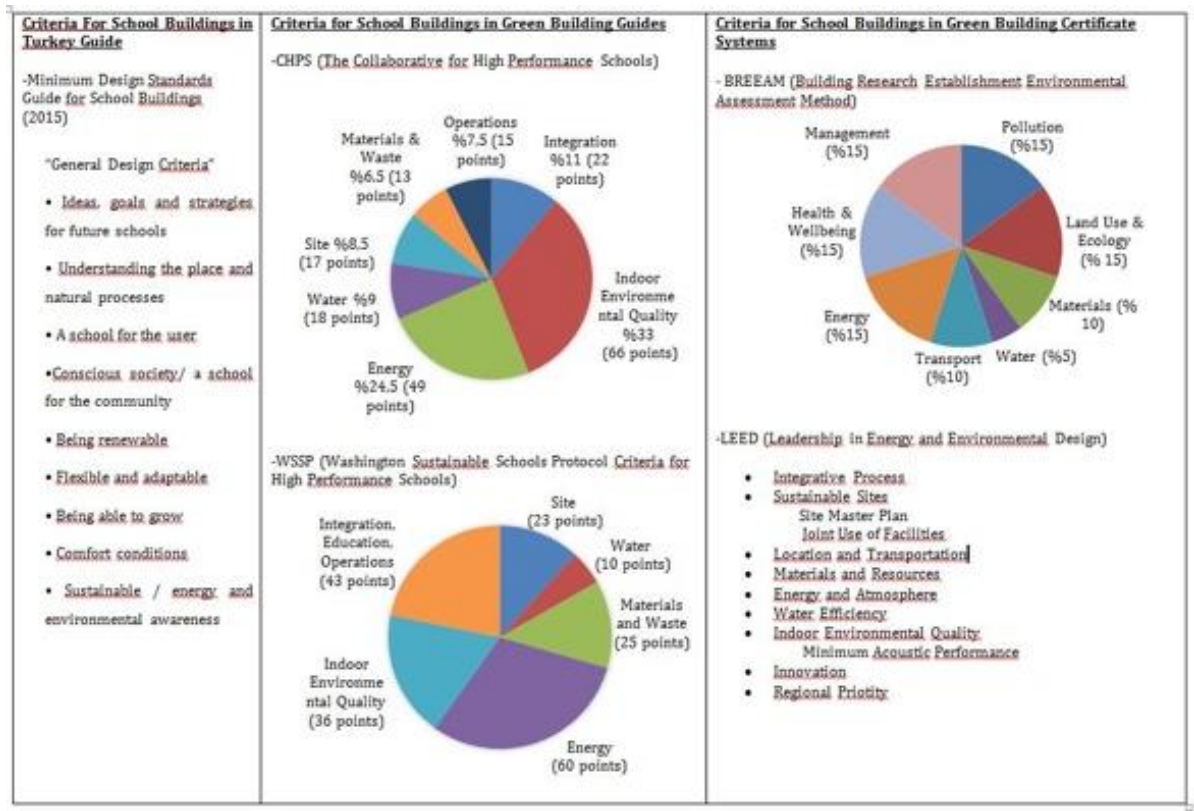

These criteria are presented under the heading "general design criteria" in the "Minimum Design Standards Guide for School Buildings" (2015) in Turkey. The Leadership in Energy and Environmental Design (LEED) certification method, on the other hand, discusses prerequisites and credits over 9 chapters and the criteria for schools are presented in the 'site master plan' and 'joint use of facilities' sections under the heading "sustainable sites". Additionally, minimum acoustic performances for schools are regulated under the heading "indoor environmental quality". Figure 1 also shows the criteria and score weights given in the Building Research Establishment Environmental Assessment Method (BREEAM), the green school design guides Washington Sustainable Schools Protocol Criteria for High Performance Schools (WSSP), and The Collaborative for
Figure 2. Criteria Guide in Turkey, Criteria on School Buildings in Green Building Guides and Criteria on School Buildings in Green Building Certification Systems (from complied URL1, URL2, URL3, URL4). 
The Re-Evaluation of Existing School Buildings in Turkey within the Context of 'Green School'

High Performance Schools (CHPS). In line with this data, green school design principles are categorized as resource conservation, comfort conditions and use of technology (Figure 3).

Figure 3. Green School Design Principles
GREEN SCHOOL DESIGN PRINCIPLES

\begin{tabular}{|c|c|c|}
\hline $\begin{array}{l}\text { Resource } \\
\text { Conservation }\end{array}$ & Comfort Conditions & $\begin{array}{l}\underline{\text { Use of }} \\
\text { Technology }\end{array}$ \\
\hline $\begin{array}{l}\text {-Energy Conservation } \\
\text {-Water Conservation } \\
\text {-Material } \\
\text { Conservation and } \\
\text { Recycling }\end{array}$ & $\begin{array}{l}\text {-Visual Comfort } \\
\text { - Acoustic Comfort } \\
\text {-Interior Air Quality }\end{array}$ & \\
\hline -Transportation & & \\
\hline $\begin{array}{l}\text {-Site Selection and } \\
\text { Placement }\end{array}$ & & \\
\hline -Building Shell & & \\
\hline
\end{tabular}

\section{Resource Conservation}

The main purpose of resource conservation is to minimize both waste generation and the consumption of natural and artificial resources throughout the life cycle of the building. Energy and water consumption in school buildings depends on the building's year of construction, its maintenance and repair conditions, occupancy rate and usage hours, and the amount and type of equipment used. It is known that the highest amount of energy consumed by school buildings are in heating and artificial lighting as provided by fossil fuels, thus generating the highest consumption cost (Carbon Trust, 2012:4). In this regard, land selection as well as settlement and transportation planning in line with the climatic characteristics of the region where the school building is located are important inputs that will contribute to energy, water and material conservation, recycling, and cost reduction. By selecting the right land, school buildings can be designed to benefit from the natural conditions of the land such as water, wind, daylight, etc. to minimize the energy used for lighting and ventilation. Other important factors in resource conservation include the correct design of building exteriors, the use of high-quality materials in the building (production, transportation, use, destruction, recycling, etc.), taking advantage of technologies that enable the use of renewable energy resources such as sunlight, wind, etc., and the use of building automation systems.

Transportation planning for the school building and its environment is also important for resource conservation. Thus, consideration of public transportation routes as well as encouraging the use of public transportation will reduce the number of vehicles used and facilitate pedestrian safety. A proper transportation arrangement will reduce waste generation as well as health care expenditures due to air 
pollution. Moreover, the negative consequences of noise pollution will be reduced as the density of vehicles will decrease.

\section{Comfort Conditions}

It is known that the time, space, infrastructure and socio-psychological dimensions of the learning environment affect student and teacher performances to a great extent. In this context, the physical conditions of classrooms are important in terms of supporting the education and learning activities that happen inside them. Hence, in addition to characteristics such as classroom size, the number of students, the cleanliness, the layout of materials in the classroom, and the compatibility and ergonomics of the equipment with student age and the nature of the learning activities; it is also essential to analyze other variables in-depth such as temperature, light, noise, color and appearance, landscaping, and access to natural daylight and airconditioning. Consequently, comfort conditions are important and necessary for healthy and productive learning and educational activities.

\section{Use of Technology}

Technologies generally used in green school designs are as follows:

- Technologies for effective use of renewable energy sources,

- Technologies used in HVAC systems,

- Building automation systems,

- Technologies for innovative construction techniques and the use of nano-technological materials.

In the "List of Suggestions for an Environmentally Responsible Design for School Buildings", Karabey (2014:27-29) suggested the following in terms of the use of technology: Foundation-to-roof insulation, the ability to withstand natural disasters such as earthquakes, storms, etc., minimizing artificial heating-cooling-ventilation systems, selecting technologies that use natural light and natural air, full building automation, the use of solar panels in water heating and energy generation, water storage and treatment, waste management, installation grouping and the use of shaft systems.

\section{THE SCHOOLS EXAMINED WITHIN SCOPE OF THE RESEARCH} $X$ Secondary School General Features and Current Situation:

The general information regarding X Secondary School is given in Table 1. The school was built in 1993 in the Yenimahalle District of Ankara. The school was designed and built as a single building with a basement, ground floor and two floors, with 24 classrooms, 2 kindergartens, 1 painting workshop, 1 music classroom, 2 information technology classrooms, 1 technology design classroom, 1 science laboratory, and 1 library. 
The Re-Evaluation of Existing School Buildings in Turkey within the Context of 'Green School'

Table 1. X secondary school general features

\begin{tabular}{|l|l|}
\hline School Name & X Secondary School \\
\hline $\begin{array}{l}\text { Construction Site- Construction } \\
\text { Year }\end{array}$ & Ankara/Yenimahalle- 1993 \\
\hline Number of Student-Teacher & 1447 Student- 78 Teacher \\
\hline Number of Classroom & 47 \\
\hline
\end{tabular}

In 2006, construction of an additional building with 24 more classrooms was started at the place allocated as a green area, and upon completion of the additional building, enrolled students for the 2007-2008 academic year. This additional building, called Block B, has 24 classrooms, 1 multi-purpose hall, 2 administration rooms, 1 teachers' room, 1 science and technology laboratory, 1 archive and 1 guidance and counselling services room. In 2013, a sports hall was built in the school yard. The layout of Blocks A and B as well as the sports hall of X Secondary School and their property boundaries are given in Figure 4. Block B is located along the north-south axis and Block A is on the eastwest axis. The schoolyard is covered with asphalt and there are only a few trees.

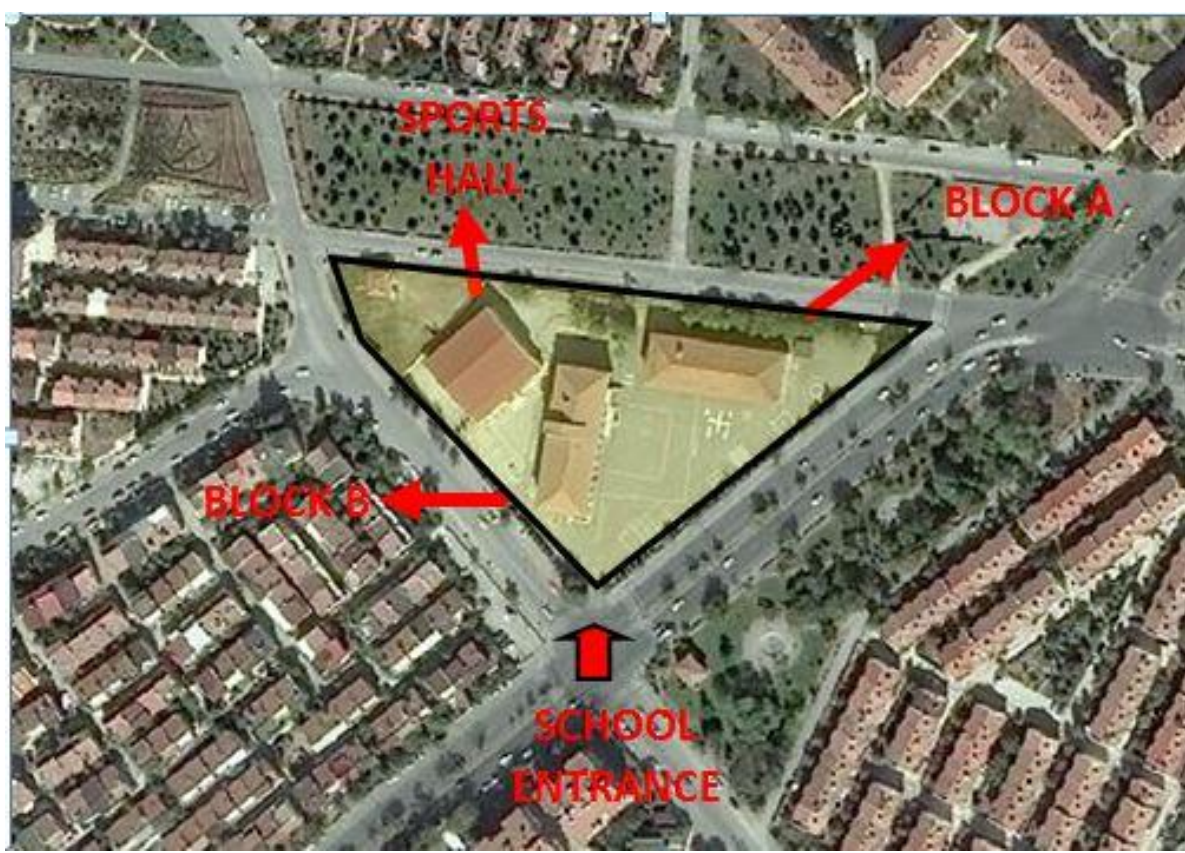

Figure 4. $X$ Secondary School A and B Blocks and Sports Hall placement in the parcel
Positive characteristics of the school include its central location with easy access, its indoor sports hall, a multi-purpose hall for various activities, a separate entrance to the kindergarten, and some green areas around the school.

On the other hand, negative characteristics of the school include the presence of roads open to traffic around the school, insufficient environmental safety, a lack of an adequate and quality playground for 
kindergarten in the school yard, a schoolyard covered with asphalt, and insufficient schoolyard walls for student security.

\section{Y Secondary School General Features and Current Situation}

General information about the Y Secondary School is given in Table 2. The school was built in 1995 in the Yenimahalle District of Ankara. The school was designed and built as a single building with a basement, ground floor, two floors with 24 classrooms, 1 kindergarten, 1 painting workshop, 1 music classroom, 1 information technology classroom, 2 technology design classrooms, 1 science laboratory and 1 library.

Table 2. Y secondary school general features

\begin{tabular}{|l|l|}
\hline School Name & Y Secondary School \\
\hline Construction Site- Construction Year & Ankara/Yenimahalle- 1995 \\
\hline Number of Student-Teacher & 484 Student- 49 Teacher \\
\hline Number of Classroom & 24 \\
\hline
\end{tabular}

The school is located in a large garden. A part of the school yard is covered with trees, and part of it is not in use. Figure 5 shows the layout and boundary of the property of the Y Secondary School building.

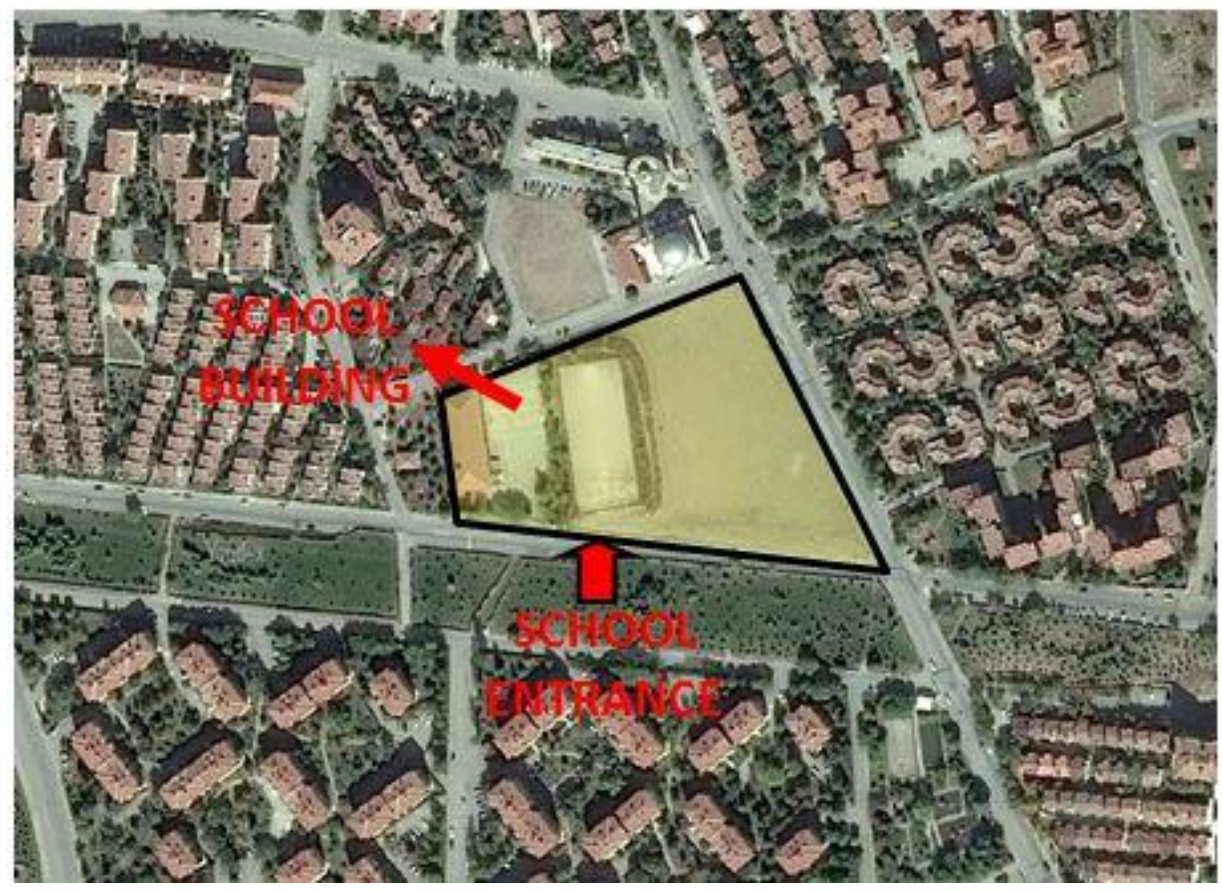

Figure 5. Y Secondary School placement in the parcel
Positive characteristics of the school include its central location with easy access, its indoor sports hall, a multi-purpose hall for various school activities, and a separate entrance to the kindergarten.

Negative characteristics of the school include the presence of roads open to traffic around the school, insufficient environmental safety, lack of an adequate and quality playground for kindergarten in the school yard, a schoolyard covered with asphalt, insufficient schoolyard walls for student security, and a part of the school that is not actively used. 
The Re-Evaluation of Existing School Buildings in Turkey within the Context of 'Green School'

\section{DATA ANALYSIS AND FINDINGS}

In the survey study, descriptive characteristics of the sample group are shown in Tables 3, 4 and 5. Accordingly, of the 267 participants, 53.6\% were students, $43.8 \%$ were parents and $2.6 \%$ were teachers. $58.7 \%$ of the students, $85.7 \%$ of the teachers and $69.8 \%$ of the parents were females. The average age of the students was 13 , the teachers was 35 and the parents was 42 .

Table 3. Distribution of participants

\begin{tabular}{|l|c|c|}
\hline & $\mathrm{n}$ & $\%$ \\
\hline Student & 143 & 53,6 \\
\hline Teacher & 7 & 2,6 \\
\hline Parents & 117 & 43,8 \\
\hline Total & 267 & 100,0 \\
\hline
\end{tabular}

Table 4. Gender Distribution of Students, Teachers and Parents

\begin{tabular}{|c|l|c|c|c|c|c|c|}
\hline \multicolumn{2}{|c|}{} & \multicolumn{2}{|c|}{ Student } & \multicolumn{2}{c|}{ Teacher } & \multicolumn{2}{c|}{ Parents } \\
\cline { 3 - 8 } \multicolumn{2}{|c|}{} & $\mathrm{n}$ & $\%$ & $\mathrm{n}$ & $\%$ & $\mathrm{n}$ & $\%$ \\
\hline \multirow{3}{*}{ Gender } & Female & 84 & 58,7 & 6 & 85,7 & 81 & 69,8 \\
\cline { 2 - 8 } & Male & 59 & 41,3 & 1 & 14,3 & 35 & 30,2 \\
\hline
\end{tabular}

Table 5. Age Distribution of Students, Teachers and Parents

\begin{tabular}{|l|l|l|l|l|l|l|}
\hline \multirow{2}{*}{} & \multicolumn{2}{|l|}{ Student } & \multicolumn{2}{c|}{ Teacher } & \multicolumn{2}{c|}{ Parents } \\
\cline { 2 - 7 } & Av. & sd & Av. & sd & Av. & sd \\
\hline Age & 13,25 & 1,14 & 35,00 & - & 41,59 & 6,77 \\
\hline
\end{tabular}

In the schools where the survey was conducted:

$41.3 \%$ of the students, $57.1 \%$ of the teachers and $34.2 \%$ of the parents stated that they strongly agree with the statement, "The opinions of students, teachers and parents should be taken into consideration in the design of the school" (Table 6).

Table 6. The distribution of the answers given to the statement "The opinions of students, teachers and parents should be taken into consideration in the design of the school."

\begin{tabular}{|c|c|c|c|c|c|c|c|}
\hline & \multicolumn{2}{|c|}{ Student } & \multicolumn{2}{|c|}{ Teacher } & \multicolumn{2}{|c|}{ Parents } \\
\hline & & $\mathrm{n}$ & $\%$ & $\mathrm{n}$ & $\%$ & $\mathrm{n}$ & $\%$ \\
\hline \multirow{6}{*}{$\begin{array}{l}\text { The opinions of } \\
\text { students, teachers } \\
\text { and parents should } \\
\text { be taken into } \\
\text { consideration in the } \\
\text { design of the school }\end{array}$} & I strongly disagree & 5 & 3,5 & 0 & 0,0 & 5 & 4,3 \\
\hline & I do not agree & 5 & 3,5 & 0 & 0,0 & 8 & 6,8 \\
\hline & I am undecided & 11 & 7,7 & 0 & 0,0 & 6 & 5,1 \\
\hline & I agree & 60 & 42,0 & 3 & 42,9 & 55 & 47,0 \\
\hline & I strongly agree & 59 & 41,3 & 4 & 57,1 & 40 & 34,2 \\
\hline & $\begin{array}{r}\text { I have no idea/I do not } \\
\text { know }\end{array}$ & 3 & 2,1 & 0 & 0,0 & 3 & 2,6 \\
\hline
\end{tabular}


It is understood that most students, teachers and parents care about being able to voice their opinions during the design of the school building. On the other hand, the majority of students, teachers and parents replied that they disagree or strongly disagree with the statement, "School social facilities should be open to use by the local public" (Table 7). It is thought that the school social facilities are not used sufficiently by the local public.

Table 7. The distribution of the answers given to the statement "School social facilities should be open to use by the local public."

\begin{tabular}{|l|r|r|r|r|r|r|r|}
\hline \multicolumn{2}{|c}{} & \multicolumn{2}{|c|}{ Student } & \multicolumn{2}{c|}{ Teacher } & \multicolumn{2}{c|}{ Parents } \\
\cline { 2 - 8 } & $\begin{array}{r}\text { I strongly } \\
\text { disagree }\end{array}$ & 33 & 23,1 & 2 & 28,6 & 21 & 17,9 \\
\hline \multirow{3}{*}{$\begin{array}{l}\text { School social } \\
\text { facilities } \\
\text { should be } \\
\text { open to use by } \\
\text { the local } \\
\text { public }\end{array}$} & I do not agree & 48 & 33,6 & 2 & 28,6 & 44 & 37,6 \\
\cline { 2 - 9 } & I am undecided & 23 & 16,1 & 1 & 14,3 & 18 & 15,4 \\
\cline { 2 - 9 } & I agree & 11 & 7,7 & 2 & 28,6 & 16 & 13,7 \\
\cline { 2 - 8 } & I strongly agree & 6 & 4,2 & 0 & 0,0 & 3 & 2,6 \\
\hline
\end{tabular}

$29.4 \%$ of the students, $28.6 \%$ of the teachers and $27.4 \%$ of the parents said that they disagree with the statement, "Open spaces in the school allow for interaction with the natural environment" (Table 8). In addition, $35 \%$ of the students, $28.6 \%$ of the teachers and $36.8 \%$ of the parents said that they disagree with the statement, "The school has sufficient green spaces" (Table 9).

Table 8. The distribution of the answers given to the statement "Open spaces in the school allow for interaction with the natural environment."

\begin{tabular}{|l|r|c|c|c|c|c|c|}
\hline \multicolumn{2}{|c|}{} & \multicolumn{2}{c|}{ Student } & \multicolumn{2}{c|}{ Teacher } & \multicolumn{2}{c|}{ Parents } \\
\cline { 2 - 8 } & $\mathrm{n}$ & $\%$ & $\mathrm{n}$ & $\%$ & $\mathrm{n}$ & $\%$ \\
\hline $\begin{array}{l}\text { Open spaces } \\
\text { in the school } \\
\text { allow for } \\
\text { interaction } \\
\text { with the } \\
\text { natural } \\
\text { environment. }\end{array}$ & $\begin{array}{r}\text { I strongly } \\
\text { disagree }\end{array}$ & 30 & 21,0 & 2 & 28,6 & 20 & 17,1 \\
\cline { 2 - 9 } & I do not agree & 42 & 29,4 & 2 & 28,6 & 32 & 27,4 \\
\cline { 2 - 9 } & I strongly agree & 12 & 8,4 & 1 & 14,3 & 4 & 3,4 \\
\cline { 2 - 9 } & $\begin{array}{r}\text { I have no } \\
\text { idea/I do not } \\
\text { know }\end{array}$ & 8 & 5,6 & 0 & 0,0 & 8 & 6,8 \\
& & 29 & 20,3 & 15,4 & 14,3 & 37 & 31,6 \\
\hline
\end{tabular}


The Re-Evaluation of Existing School Buildings in Turkey within the Context of 'Green School'

Moreover, in the responses given to the questions asking for "suggestions regarding deficiencies in the school building and its surroundings in order to improve the efficiency of environmental education", it is observed that the participants mostly referred to the green areas and their arrangement, the size of the school yard, the trees, etc. In this context, it is understood that the schools' open spaces do not provide sufficient opportunities for interaction with the natural environment, while the schools' green spaces are also not sufficient in terms of quality or quantity.

Table 9. The distribution of the answers given to the statement "The school has sufficient green spaces"

\begin{tabular}{|r|r|r|c|c|c|c|c|}
\hline \multicolumn{2}{|c|}{} & \multicolumn{2}{|c|}{ Student } & \multicolumn{2}{|c|}{ Teacher } & \multicolumn{2}{|c|}{ Parents } \\
\cline { 2 - 10 } & $\mathrm{n}$ & $\%$ & $\mathrm{n}$ & $\%$ & $\mathrm{n}$ & $\%$ \\
\hline $\begin{array}{l}\text { The school has } \\
\text { sufficient green spaces. }\end{array}$ & I strongly disagree & 46 & 32,2 & 3 & 42,9 & 46 & 39,3 \\
\cline { 2 - 10 } & I do not agree & 50 & 35,0 & 2 & 28,6 & 43 & 36,8 \\
\cline { 2 - 9 } & I am undecided & 24 & 16,8 & 2 & 28,6 & 5 & 4,3 \\
\cline { 2 - 9 } & I agree & 13 & 9,1 & 0 & 0,0 & 16 & 13,7 \\
\cline { 2 - 9 } & I strongly agree & 6 & 4,2 & 0 & 0,0 & 6 & 5,1 \\
\cline { 2 - 9 } & I have no idea/I do & 4 & 2,8 & 0 & 0,0 & 1 & 0,9 \\
\hline
\end{tabular}

$25.2 \%$ of the students, $14.3 \%$ of the teachers and $34.2 \%$ of the parents stated that they agree with the statement, "Noise pollution is quite high in the school environment" (Table 10). In addition, $16.8 \%$ of the students, $28.6 \%$ of the teachers and $30.8 \%$ of the parents agreed with the statement, "The noise level in the classrooms is disturbing" (Table 11). In this line, it is seen that a majority of the participants think that the environment in which the school is located is noisy and that the noise in the classrooms is disturbing.

Table 10. The distribution of the answers given to the statement "Noise pollution is quite high in the school environment"

\begin{tabular}{|c|c|c|c|c|c|c|c|}
\hline & \multicolumn{2}{|c|}{ Student } & \multicolumn{2}{|c|}{ Teacher } & \multicolumn{2}{|c|}{ Parents } \\
\hline & & $\mathrm{n}$ & $\%$ & $\mathrm{n}$ & $\%$ & $\mathrm{n}$ & $\%$ \\
\hline \multirow{6}{*}{$\begin{array}{l}\text { Noise } \\
\text { pollution is } \\
\text { quite high in } \\
\text { the school } \\
\text { environment. }\end{array}$} & $\begin{array}{r}\text { I strongly } \\
\text { disagree }\end{array}$ & 8 & 5,6 & 1 & 14,3 & 8 & 6,8 \\
\hline & I do not agree & 41 & 28,7 & 4 & 57,1 & 39 & 33,3 \\
\hline & I am undecided & 27 & 18,9 & 0 & 0,0 & 13 & 11,1 \\
\hline & I agree & 36 & 25,2 & 1 & 14,3 & 40 & 34,2 \\
\hline & I strongly agree & 29 & 20,3 & 1 & 14,3 & 17 & 14,5 \\
\hline & $\begin{array}{r}\text { I have no idea/I } \\
\text { do not know }\end{array}$ & 2 & 1,4 & 0 & 0,0 & 0 & 0,0 \\
\hline
\end{tabular}


Table 11. The distribution of the answers given to the statement "The noise level in the classrooms is disturbing"

\begin{tabular}{|l|r|c|c|c|c|c|c|}
\hline \multicolumn{2}{|c|}{} & \multicolumn{2}{c|}{ Student } & \multicolumn{2}{c|}{ Teacher } & \multicolumn{2}{c|}{ Parents } \\
\cline { 3 - 8 } & $\mathrm{n}$ & $\%$ & $\mathrm{n}$ & $\%$ & $\mathrm{n}$ & $\%$ \\
\hline $\begin{array}{l}\text { The noise } \\
\text { level in the } \\
\text { classrooms } \\
\text { is disturbing }\end{array}$ & $\begin{array}{r}\text { I strongly } \\
\text { disagree }\end{array}$ & 12 & 8,4 & 0 & 0,0 & 6 & 5,1 \\
\cline { 2 - 9 } & I do not agree & 29 & 20,3 & 2 & 28,6 & 23 & 19,7 \\
\cline { 2 - 8 } & I am undecided & 43 & 30,1 & 0 & 0,0 & 24 & 20,5 \\
\cline { 2 - 8 } & I agree & 24 & 16,8 & 2 & 28,6 & 36 & 30,8 \\
\cline { 2 - 8 } & I strongly agree & 28 & 19,6 & 2 & 28,6 & 15 & 12,8 \\
\cline { 2 - 8 } & I have no idea/I \\
do not know & 7 & 4,9 & 1 & 14,3 & 13 & 11,1 \\
\hline
\end{tabular}

$43.4 \%$ of the students, $71.4 \%$ of the teachers and $44.4 \%$ of the parents agreed with the statement, "Lighting levels in classrooms are adequate" (Table 12).

Table 12. The distribution of the answers given to the statement "Lighting levels in classrooms are adequate"

\begin{tabular}{|l|r|c|c|c|c|c|c|}
\hline \multicolumn{2}{|c|}{} & \multicolumn{2}{c|}{ Student } & \multicolumn{2}{c|}{ Teacher } & \multicolumn{2}{c|}{ Parents } \\
\cline { 3 - 8 } \multicolumn{2}{|c|}{} & $\mathrm{n}$ & $\%$ & $\mathrm{n}$ & $\%$ & $\mathrm{n}$ & $\%$ \\
\hline $\begin{array}{l}\text { Lighting } \\
\text { levels in } \\
\text { classrooms } \\
\text { are }\end{array}$ & $\begin{array}{r}\text { I strongly } \\
\text { disagree }\end{array}$ & 12 & 8,4 & 0 & 0,0 & 6 & 5,1 \\
\cline { 2 - 8 } adequate & I do not agree & 29 & 20,3 & 2 & 28,6 & 23 & 19,7 \\
\cline { 2 - 8 } & I am undecided & 43 & 30,1 & 0 & 0,0 & 24 & 20,5 \\
\cline { 2 - 8 } & I agree & 24 & 16,8 & 2 & 28,6 & 36 & 30,8 \\
\cline { 2 - 8 } & $\begin{array}{r}\text { I have no idea/I } \\
\text { do not know }\end{array}$ & 7 & 4,9 & 1 & 14,3 & 13 & 11,1 \\
\hline
\end{tabular}

$29.4 \%$ of students, $42.9 \%$ of teachers and $35.9 \%$ of parents responded that they agreed with the statement, "The temperature of the classrooms is adequate" (Table 13).

Table 13. The distribution of the answers given to the statement "The temperature of the classrooms is adequate"

\begin{tabular}{|c|c|c|c|c|c|c|c|}
\hline & \multicolumn{2}{|c|}{ Student } & \multicolumn{2}{|c|}{ Teacher } & \multicolumn{2}{|c|}{ Parents } \\
\hline & & $\mathrm{n}$ & $\%$ & $\mathrm{n}$ & $\%$ & $\mathrm{n}$ & $\%$ \\
\hline \multirow{6}{*}{$\begin{array}{l}\text { The } \\
\text { temperature } \\
\text { of the } \\
\text { classrooms is } \\
\text { adequate }\end{array}$} & I strongly disagree & 28 & 19,6 & 0 & 0,0 & 17 & 14,5 \\
\hline & I do not agree & 26 & 18,2 & 1 & 14,3 & 25 & 21,4 \\
\hline & I am undecided & 30 & 21,0 & 2 & 28,6 & 20 & 17,1 \\
\hline & I agree & 42 & 29,4 & 3 & 42,9 & 42 & 35,9 \\
\hline & I strongly agree & 10 & 7,0 & 1 & 14,3 & 5 & 4,3 \\
\hline & $\begin{array}{r}\text { I have no idea/I do } \\
\text { not know }\end{array}$ & 7 & 4,9 & 0 & 0,0 & 8 & 6,8 \\
\hline
\end{tabular}


The Re-Evaluation of Existing School Buildings in Turkey within the Context of 'Green School'

$28 \%$ of the students, $42.9 \%$ of the teachers and $37.6 \%$ of the parents stated that they agreed with the statement, "Ventilation is adequate in the classrooms" (Table 14). Thus, it is understood that the lighting, temperature and ventilation in the classrooms are relatively adequate.

Table 14. The distribution of the answers given to the statement "Ventilation is adequate in the classrooms"

\begin{tabular}{|l|r|c|c|c|c|c|c|}
\hline \multicolumn{2}{|c|}{} & \multicolumn{2}{c|}{ Student } & \multicolumn{2}{c|}{ Teacher } & \multicolumn{2}{c|}{ Parents } \\
\cline { 3 - 8 } \multicolumn{2}{|c|}{} & $\mathrm{n}$ & $\%$ & $\mathrm{n}$ & $\%$ & $\mathrm{n}$ & $\%$ \\
\hline $\begin{array}{l}\text { Ventilation } \\
\text { is adequate } \\
\text { in the } \\
\text { classrooms. }\end{array}$ & $\begin{array}{r}\text { I strongly } \\
\text { disagree }\end{array}$ & 26 & 18,2 & 1 & 14,3 & 16 & 13,7 \\
\cline { 2 - 8 } & I do not agree & 34 & 23,8 & 2 & 28,6 & 25 & 21,4 \\
\cline { 2 - 8 } & I am undecided & 31 & 21,7 & 1 & 14,3 & 15 & 12,8 \\
\cline { 2 - 8 } & I agree & 40 & 28,0 & 3 & 42,9 & 44 & 37,6 \\
\cline { 2 - 8 } & $\begin{array}{r}\text { I strongly agree } \\
\text { I have no idea/I }\end{array}$ & 5 & 3,5 & 0 & 0,0 & 5 & 4,3 \\
\hline
\end{tabular}

According to the results of the analyses, a comparison of the scores of students, teachers and parents (Table 15) showed that there was no statistically significant difference between the opinions of students, teachers and parents about the positive relationship between school, the environment, and environmental education ( $p>0.05$ ). Although it is not statistically significant, teachers thought that the positive relationship between school, the environment, and environmental education is stronger as compared with students and parents.

There was no statistically significant difference between the opinions of students, teachers and parents about the negative relationship between school, the environment, and environmental education ( $p>0.05)$. Although it is not statistically significant, students and parents thought that the negative relationship between school, the environment, and environmental education is stronger as compared with teachers.

There was no statistically significant difference between the opinions of students, teachers and parents about the physical properties of the school building ( $p>0.05)$. Although it is not statistically significant, teachers thought that the physical properties of the school building are better as compared with students and parents.

There was no statistically significant difference between the opinions of students, teachers and parents about the transportation characteristics around the school building ( $p>0.05$ ). Although it is not statistically significant, teachers thought that the transportation facilities around the school building are better as compared with students and parents.

There was no statistically significant difference between the opinions of students, teachers and parents about classrooms ( $p>0.05)$. Although it is not statistically significant, teachers thought that classrooms are better as compared with students and parents. 
Table 15. Comparison of the Scale Scores of Students, Teachers and Parents

\begin{tabular}{|c|c|c|c|c|c|c|}
\hline & & $\mathrm{n}$ & Av. & sd & $\mathrm{F}$ & $\mathrm{p}$ \\
\hline \multirow{3}{*}{$\begin{array}{l}\text { Between School and Environment } \\
\text { and Environmental Education } \\
\text { Positive Relationship }\end{array}$} & Student & 143 & 2,35 & 0,76 & \multirow{3}{*}{2,505} & \multirow{3}{*}{0,084} \\
\hline & Teacher & 7 & 2,95 & 0,54 & & \\
\hline & Parents & 117 & 2,28 & 0,81 & & \\
\hline \multirow{3}{*}{$\begin{array}{l}\text { Between School and Environment } \\
\text { and Environmental Education } \\
\text { Negative Relationship }\end{array}$} & Student & 143 & 3,08 & 0,80 & \multirow{3}{*}{0,188} & \multirow{3}{*}{0,829} \\
\hline & Teacher & 7 & 2,89 & 0,80 & & \\
\hline & Parents & 117 & 3,07 & 0,81 & & \\
\hline \multirow{3}{*}{$\begin{array}{l}\text { Physical Properties of School } \\
\text { Building }\end{array}$} & Student & 143 & 2,09 & 0,54 & \multirow{3}{*}{1,376} & \multirow{3}{*}{0,254} \\
\hline & Teacher & 7 & 2,48 & 0,50 & & \\
\hline & Parents & 117 & 2,12 & 0,66 & & \\
\hline \multirow{3}{*}{$\begin{array}{l}\text { Trabsportation Properties of } \\
\text { School Building }\end{array}$} & Student & 143 & 3,57 & 0,98 & \multirow{3}{*}{2,377} & \multirow{3}{*}{0,095} \\
\hline & Teacher & 7 & 4,38 & 0,71 & & \\
\hline & Parents & 117 & 3,63 & 0,95 & & \\
\hline \multirow{3}{*}{ Opinions About Classrooms } & Student & 143 & 2,71 & 0,74 & \multirow{3}{*}{1,014} & \multirow{3}{*}{0,364} \\
\hline & Teacher & 7 & 3,02 & 0,91 & & \\
\hline & Parents & 117 & 2,61 & 0,95 & & \\
\hline
\end{tabular}

According to the answers given to the other statements in the survey, most of the participants thought that the characteristics of the school building did not affect academic achievement positively and that the schools did not have an aesthetically qualified appearance, that they were not always clean and well-maintained, and that solutions for the disabled were insufficient in the school buildings. In addition, the distribution of the answers given to the expressions about the transportation characteristics of the school indicated that the schools are easily accessible by foot, public transportation or bicycle, but that the bicycle park is insufficient.

On the other hand, the majority of participants responded that 'they have no idea/do not know' to the following statements in the survey:

"The school building itself supports environmental education."

"Temperature and heating measurements in the school can be observed by students."

"The school's energy consumption can be monitored by students."

"Students are informed about the school's water consumption."

"Water and energy savings can be achieved through the active participation of students."

"The materials used in the school building do not have any harmful effects on health."

"Renewable energy resources are used in the school."

"The type of fuel used in the school creates hazardous waste to the environment."

"The smell of the materials used in the school building is disturbing."

Although many studies (Cole, 2013; Taylor, 2013; Bradley, 1996) emphasized that school buildings can be used as an important tool to educate individuals about the environment and increase environmental literacy, the majority of the participants answered these statements as 'I 
have no idea / I do not know' shows that school buildings do not have the qualifications that can be used as a tool for learning by living in environmental education. In addition, it was observed that there was not enough awareness among the participants regarding these features of the school building, and the participants are not questioning the issues such as energy consumption of the school, the type of fuel used, the type of waste generated and its impact on the environment, etc. As Atasoy and Ertürk (2008) stated in their study; these findings show that the quality, scope and depth of environmental education is negative and insufficient, and that the educational environment and courses are not sufficiently environmentalized.

Participants' opinion that open spaces in schools do not provide enough opportunities for interaction with the natural environment, green spaces in schools are not sufficient in terms of quality and quantity, and the answers to the "suggestions that are thought to be lacking in the school building and its surroundings, which will increase efficiency in environmental education activities", green areas and the arrangement of these areas, the size of the school garden, afforestation, etc. is in line with the findings of Özdemir and Çorakçı's (2011) study that "gardens are insufficient for activities, most of the students like schools with large gardens and they are not satisfied with school gardens with low landscape values".

Regarding the noise level, which is one of the most important factors affecting learning in classrooms, most of the participants think that the environment where the school is located is noisy and the noise in the classrooms is at a disturbing level. In the study of Seven and Engin (2008), the participants stated that their school was located in a very noisy place due to its location. Küçükoğlu and Özerbaş (2004) stated that noise is a factor that hinders the success of students and teachers because it reduces attention and makes concentration on the subject difficult, and that a $19 \%$ increase in energy consumption has been demonstrated experimentally as a result of comparing studies in loud environments with studies in a quiet environment. They stated that noise slows down and dulls mental processes, shadows reasoning power, and reduces the success of students and teachers.

According to Kayıhan and Tönük, (2011), besides the central location of the education building, its transportation network with the surrounding settlements is also very important. Establishing the connection of the school with the surrounding residential areas through various pedestrian and bicycle paths, isolating these roads from vehicle roads as much as possible, providing sufficient lighting for night use, etc. such criteria directly affect the quality of educational building-society interaction. It is also important that the school building's sports facilities, open spaces, library, meeting hall and classroom spaces are designed to be used jointly with the society at appropriate times (Kayıhan \& Tönük, 2011). Nevertheless among the answers given to the statements in the questionnaire, the thought that the social facilities of 
schools cannot be used sufficiently by the immediate environment is considered as a negative feature in this sense, while the distribution of the answers given to the statements about the transportation feature of the school is considered as a positive feature.

\section{CONCLUSIONS AND RECOMMENDATIONS}

It is clear that some of the recommendations for re-evaluating school buildings within the scope of the green school concept are easily applicable as they require low intervention levels, yet there is a need to use technology in most of them and this requires a sufficient budget. In this regard, even though the initial investment costs of the arrangements, renovations and technological systems to be integrated in these schools will be high, resource conservation will be provided to a great extent as operation and maintenance costs will be lowered. Re-evaluating existing school buildings within the scope of "green schools" and designing new school buildings as "green schools" will ensure the efficient use of resources, environmental protection, healthy and comfortable environments as well as reinterpreting the school as a learning tool. This research and future analyses in this area are significant both in terms of improving the situation of existing school buildings and providing input on the design of new green school buildings in line with user opinions and experiences. Furthermore, the idea that schools are important tools for creating sustainable environmental awareness in future generations should always be taken into consideration. Thus, investments must be increased, and green schools must be supported along the lines of viewing school buildings themselves as learning tools.

Construction of new school buildings according to green school design principles requires a large set of criteria starting from the pre-design process and extending to land selection and planning, analyzing natural environmental characteristics and potential climate data, designing building exteriors accordingly, transportation planning, and building material selection among many other factors. Recommendations for the re-evaluation of existing school buildings as green schools within the limits of the research are as follows:

- Schools should cooperate more closely with voluntary organizations and local authorities on environmental education.

- Within the scope of the "green schools project", pilot schools should be identified, the necessary implementations applied, and awareness of students, teachers and parents should be increased.

- User participation should be ensured in school designs and renovation work, and experts from various disciplines should 
The Re-Evaluation of Existing School Buildings in Turkey within the Context of 'Green School'

be consulted (architects, engineers, educators, sociologists, etc.).

- Schools should be designed in such a way as to enable interaction with the natural environment and to contribute positively to the environment in which they are located.

- The social facilities of schools should be made available for use by the local community and educational structures should be intertwined with society.

- Strengths and weaknesses of schools should be analyzed; physical problems and potentials that affect educational performance positively/negatively should be identified, and the problems should be eliminated while opportunities are improved.

- Schools should have visual and audio warning tools for environmental education.

\section{Recommendations on resource conservation:}

- In maintenance, repair, and renovation work to improve physical conditions in schools, solutions should enable the use of natural lighting and natural air conditioning as much as possible.

- Negative characteristics of schools that cause heat loss should be identified and the necessary insulation work should be completed to provide energy conservation.

- Water consumption of schools should be determined, water installation systems should be reviewed, and photocell taps should be installed in sinks to save water.

- Photovoltaic solar panels should be installed to ensure that solar energy is utilized, and students should see how these systems work.

- Rainwater should be collected and used, and gray water should be treated and reused in suitable areas.

- Bicycle stands should be provided at schools where bicycle transportation is safe and convenient, but with limited parking.

\section{Recommendations on comfort conditions:}

- Visual comfort and indoor air quality should be improved with solutions where natural lighting and natural air conditioning can be used in order for resource conservation.

- Acoustic problems should be identified especially in classrooms, and sound absorbers or reflective materials should be used where necessary to improve auditory comfort.

- Building materials and products used in schools that emit pollutant gases into the environment and cause harmful 
health effects should be identified and replaced with new ones that are not harmful to the environment and are easy to maintain and repair. In addition, cleaning materials that do not contain any harmful ingredients should be preferred for the maintenance and cleaning of schools.

- In order to actively use the open spaces in schools, floor covering materials, green areas, playgrounds, etc. should be rearranged and renovated relevant to students' ages, and the nature of the activities performed.

- School interiors should be designed to develop students' discovery skills, and the layout of furniture and equipment (such as the position, angle, layout, etc.) should be rearranged suitably.

- Spaces in schools should be organized in a way that allows for flexibility of use with developing technology and changing education theories.

\section{Recommendations on the use of technology:}

- Visual comfort should be provided by using artificial lighting systems sensitive to daylight and motion sensor artificial lighting in places where natural lighting is not available.

- HVAC (heating-ventilation-air-conditioning) systems that improve indoor air quality should be used in places where natural ventilation is not sufficient.

Noise sources should be determined by creating a noise map around the school and products related to wall and wall opening (facade claddings, doors, windows, transparent surfaces, etc.) should be renewed accordingly.

\section{ACKNOWLEDGEMENTS/NOTES}

This research study was made within the scope of the thesis titled "Examination of Green School Design Criteria: Sampling on Existing School Buildings in Turkey" carried out by Sağra ÇAKIR under the supervision of Assoc. Prof. Gökçe TUNA TAYGUN at Yıldız Technical University, Institute of Science, Department of Architecture.

\section{CONFLICT OF INTEREST}

No conflict of interest was declared by the authors.

FINANCIAL DISCLOSURE

The authors declared that this study has received no financial support.

\section{ETHICS COMMITTEE APPROVAL}

Ethics committee approval was not required for this article.

\section{LEGAL PUBLIC/PRIVATE PERMISSIONS}


The Re-Evaluation of Existing School Buildings in Turkey within the Context of 'Green School'

In this research, the necessary permissions were obtained from the relevant participants (individuals, institutions, and organizations) during the survey, in-depth interview, focus group interview, observation or experiment.

\section{REFERENCES}

Avcl, N. (2013). Minimum Design Standards Guide for School Buildings 2013. First Word. (p.VIII). Ministry of Education Department of Construction and Real Estate.

Atasoy, E. and Ertürk, H., (2008). A Field Study About Environmental Knowledge and Attitudes of Elementary School Students, Erzincan University Journal of Education Faculty, 10(1):105-122.

Baker, L., Bernstein, H. (2012). "The impact of school buildings on student health and performance", McGraw-Hill Research Foundation, The Center for Green Schools at USGBC, p. 1-4, http://www.usgbc.org/Docs/Archive/General/Docs18534.pdf. (E.T. 05.11.2015).

Barrett, P., Zhang, Y., Moffat, J., Kobbacy, K., (2013). A holistic, multi-level analysis identifying the impact of classroom design on pupils learning, Building and Environment, 59:678-689.

Berry, M.A., (2002). "Healthy School Environment and Enhanced Educational Performance The Case Of Charles Young Elementary School Washington DC", p.19. https://files.eric.ed.gov/fulltext/ED473985.pdf. (E.T.15.10.2019).

Bradley, W. S., (1996). Perceptions About the role of Architecture in Education. Doctoral Dissertation, University of Virginia, USA, p.105.

Carbon Trust, (2012). "Schools", Sector Overview, London, UK, p.4. https://www.carbontrust.com/media/39232/ctv019_schools.pdf. (E.T. 06.12.2015).

Cole, L. B., (2013). The Teaching Green School Building: Exploring the Contributions of School Design to Informal Environmental Education. A Dissertation Submitted in Partial Fulfillment of The Requirements for The Degree of Doctor of Philosophy, Architecture and Natural Resources and Environment, University of Michigan.

Çakır, S. (2017). Examination of green school design criteria: sampling on existing school buildings in Turkey. Master Thesis, Yıldız Technical University Institute of Science, Istanbul, p.180-185.

Earthman, G. (2009). Planning Educational Facilities. (3 ${ }^{\text {th }}$ Ed.) Lanham, United States. Rowman and Littlefield Education.

Edwards, B. W., (2006). Environmental Design and Educational Performance with Particular Reference to 'Green' Schools in Hampshire and Essex, Research in Education, 76, p. 14-32.

Figueiro, M., \& Rea, M. S. (2010). Lack of shortwavelength light during the school day delays dim light melatonin onset (DLMO) in middle school students, Neuroendocrinology Letters, 31(1).

Ford, A. (2008). Designing the Sustainable School. Bastow: Images Publishing. 
Gelder, J. (1998). Teaching Environmentally Sustainable Design in Schools. PEB Exchange, Programme on Educational Building, 1998/09, OECD Publishing, p.14-16. Gelfand, L. and Freed, E. C. (2010). Sustainable School Architecture: Design for Elementary and Secondary School. USA: John Wiley and Sons Inc.

Gök H. and Gürol M., (2002). In Primary Education Usage Structural of School's Building About Ergonomics and Time (Sample of Elazı̆ Country), Firat University, Journal of International Social Sciences, 12 (2):263-273.

Green Buildings Reference Guide, (2014). Certified Green Building and Contributors in Turkey. Green schools project, XXI, Green Buildings Reference Guide, p.4.

Heschong, L., \& Mahone, D. (2003). "Daylighting in Schools: Reanalysis Report". California Energy Commission.

Hines, E. W., (1996). Building Condition and Student Achievement and Behavior. Dissertation Submitted to the Faculty of The Virginia Polytechnic Institute and State University in Partial Fulfillment of The Requirements for The Degree of Doctor of Education, p.48-55.

IEEP, (1994). "An Environmental Education Curriculum for Pre-service Education of Secondary Level Teachers", UNESCO-UNEP- IEEP: Environmental Education Series, (43).

Karabey, H., (2014). List of recommendations for environmentally friendly design in educational facilities, Journal of Ege Mimarlık, 87: 272.

Karatekin, K. and Çetinkaya, G., (2013). Evaluation of School Gardens in terms of Environmental Education (Manisa Province Sample), Journal of International Social Research, 6(27): 307-315.

Kats, G. (2006). "Greening America's Schools Costs and Benefits", A Capital E Report. https://www.usgbc.org/sites/default/files/Greening_Americas_Schools. pdf. (E.T. 14.10.2019).

Kayıhan K. S. and Tönük, S., (2011). Elementary School Buildings with the Direction of Sustainability Awareness Construction, Journal of Polytechnic, 14 (2), 163-171.

Küçükoğlu, A. and Özerbaş, M. A., (2004). Eğitim Ergonomisi ve Sınıf İçi Fiziksel Değişkenlerin Organizasyonu (Educational Ergonomics and the Organization of in-class Physical Variables), Atatürk University Journal of Social Sciences Institute, 4 (2):121-134.

Lackney J. A. (2001). The State of Post-Occupancy Evaluation in the Practice of Educational Design, Paper presented at the Environmental Design Research Association, EDRA 32, Edinburgh, Scotland, Jul 05, 2001.

MEB, (2017). "National Education Statistics Formal Education 2016/'17. Ministry of National Education Strategy Development Directorate Official Statistics Program Publication", MEB, p.239-247. 
The Re-Evaluation of Existing School Buildings in Turkey within the Context of 'Green School'

MEB, (2018). "National Education Statistics Formal Education 2017/'18. Ministry of National Education Strategy Development Directorate Official Statistics Program Publication", MEB, p. 18-21.

Oetinger, J. W. (2010). Green schools: Constructing and Renovating School Facilities with the Concept of Sustainability. Doctoral thesis, Lindenwood University: USA, p.15-33.

Özbayraktar, M., (2005). Effects of Information Technologies on Learning Space Planning-in the case of Classrooms and Library Spaces of Primary Schools, The Turkish Online Journal of Educational Technology, 4: 101-108, Turkey.

Özdemir, A., and Çorakçı, M., (2011). Renovation of Ankara's Schoolyards by Participatory Approaches, Journal of National Education, 189:7-20.

Saltık A. (1997). Sustainable Management of Natural Resources: A Conceptual Approach, Implementation of Sustainable Development, Discussion Meeting, 11-12 December 1997, Turkey Environment Foundation Publications, Turkey, p. 27-33.

Seven, M. A and Engin, A. 0., (2008). Öğrenmeyi Etkileyen Faktörler (Factors Affecting Learning), Atatürk University Journal of Social Sciences Institute, 12(2):189-212.

Taylor, Z., (2013). “Green Schools Investment Guide: for healthy, effcient and inspiring learning spaces", The Center for Green Schools at USGBC, p.3-4.

Ünal, S. and Dımışkı, E., (1999). UNESCO-UNEP Himayesinde Çevre Eğitiminin Gelişimi ve Türkiye'de Ortaöğretim Çevre Eğitimi (Development of Environmental Education in the UNESCO-UNEP auspices and Secondary Environmental Education in Turkey), Hacettepe University Journal of Education, 16-17: 142 - 154.

URL-1. Retrieved from https://iedb.meb.gov.tr/meb_iys_dosyalar/201 5_08/17032245_2015asgaritasarmklavuzu.pdf (14.10.2019)

URL-2. Retrieved from https://chps.net/sites/default/files/CHPS\% 20Core\%20Criteria\%20v3\%20Final\%206.14.19\%20protected.pdf. (11.08.2019)

URL-3. Retrieved from https://www.k12.wa.us/sites/default/fil es/public/schfacilities/programs/highperformanceschools/2018wssp. $\operatorname{pdf}(02.01 .2020)$

URL-4. Retrieved from https://www.fgould.com/media/resources/file s/schools_for_the_future.pdf

USGBC (United States Green Building Council), (2009). Leed 2009 for Schools New Construction and Major Renovations Rating System. p.10, https://www.usgbc.org/sites/default/files/LEED\%202009\%20RS_SCH OOLS_07.01.16_clean.pdf (E.T. 09.10.2019).

WGBC (World Green Building Council), (2013). Global snapshot: the greening of schools influencing the built environment. WGBC, p.3-6 http://www.worldgbc.org/files/5913/6740/8939/WorldGBC_Global_S napshot_-_Green_Schools_ONLINE-043013_1.pdf (E.T.11.11.2015). 
Yudelson, J. (2008). The Green Building Revolution. Washington: Island Press.

\section{Resume}

Sağra Çakır: ORCID: 0000-0003-3016-7883, Graduated from the Department of Architecture at Dokuz Eylül University as an architect in 2011. She worked as a research assistant in the Department of Architecture at Dokuz Eylül University in 2012. She completed her master's thesis on "Green School Design Principles" at YIldiz Technical University in 2017. She has been working as an architect at the Republic of Turkey Ministry of Culture and Tourism since 2013. Her study areas are sustainable design, green schools, restoration of immovable cultural heritages.E-mail: sagra.cakir@gmail.com

Gökçe Tuna Taygun: ORCID: 0000-0002-1852-5548, She graduated from Ylldiz Technical University, Faculty of Architecture, Department of Architecture in 1995 and completed his master's degree in 1998 and his doctorate in 2005. She has been working as a research assistant at YTU Faculty of Architecture Department of Construction Science since 1996. She has several national and international academic studies such as articles, reports, research projects on green building and construction products, life cycle assessment and environmental impact assessment.E-mail: tuna@yildiz.edu.tr 